IZA DP No. 10043

UK Trades Unions and the Problems of Collective Action

Paul Willman

Alex Bryson

John Forth

July 2016 


\title{
UK Trades Unions and the Problems of Collective Action
}

\author{
Paul Willman \\ London School of Economics \\ Alex Bryson \\ University College London \\ and IZA \\ John Forth \\ National Institute of Economic and Social Research
}

\author{
Discussion Paper No. 10043 \\ July 2016
}

IZA

P.O. Box 7240
53072 Bonn
Germany

Phone: +49-228-3894-0

Fax: +49-228-3894-180

E-mail: iza@iza.org

\begin{abstract}
Any opinions expressed here are those of the author(s) and not those of IZA. Research published in this series may include views on policy, but the institute itself takes no institutional policy positions. The IZA research network is committed to the IZA Guiding Principles of Research Integrity.

The Institute for the Study of Labor (IZA) in Bonn is a local and virtual international research center and a place of communication between science, politics and business. IZA is an independent nonprofit organization supported by Deutsche Post Foundation. The center is associated with the University of Bonn and offers a stimulating research environment through its international network, workshops and conferences, data service, project support, research visits and doctoral program. IZA engages in (i) original and internationally competitive research in all fields of labor economics, (ii) development of policy concepts, and (iii) dissemination of research results and concepts to the interested public.
\end{abstract}

IZA Discussion Papers often represent preliminary work and are circulated to encourage discussion. Citation of such a paper should account for its provisional character. A revised version may be available directly from the author. 


\section{ABSTRACT}

\section{UK Trades Unions and the Problems of Collective Action ${ }^{1}$}

This paper looks at the financial resources of trades unions in the UK, both updating previous work and attempting to understand the management of first and second order collective action problems. First order problems refer to the problems of initiating collective action and second order problems refer to the management of collective action organisations. Unions are 'cost disease' organisations in which expenditure outstrips inflation but revenue may not. Their economic model cannot survive without some form of external subsidy. Both aggregate and case study data - from the largest UK union, Unite - are presented to illustrate the cost disease problem and to suggest options for its management.

JEL Classification: trade unions, collective action

Keywords: $\quad J 51$

Corresponding author:

Alex Bryson

Department of Social Science

University College London

Gower Street

London WC1E 6BT

United Kingdom

E-mail: a.bryson@ucl.ac.uk

\footnotetext{
${ }^{1}$ Paul Willman is also a Council Member of the Advisory, Conciliation and Arbitration Service, but the views expressed in this paper are his own. We are grateful to colleagues at the LERA Conference, San Francisco, 2016, for their comments and particularly the discussant, Professor Robert Flanagan, and to Paul Nowak and Edward Sweeney for comments on earlier drafts.
} 


\section{Introduction}

Unions in Great Britain have faced long term decline in at least two senses. First, union membership has declined since the late 1970's. Second, the number of unions has declined, over a longer period, leading to a greater concentration of a reduced membership (Buchanan, 1981; Willman et al., 1993). The mechanisms underlying the decline in membership have been well analysed using successive Workplace Employment Relations Surveys (WERS) (e.g. Brown et al, 2009). The primary mechanism for the reduction in the number of unions has been merger and acquisition ('transfer of engagements'; see Undy 2008).

The intent of this paper is twofold. The first is to address this long term decline in resourcing terms. Specifically, we argue that British unions lack resources effectively to manage first and second-order collective action problems, and that the resource requirements to manage such problems have been increasing. The symptoms of decline may be endogenous (Willman 2005), but the triggers exogenous; we examine the relationship between exogenous triggers and endogenous consequences by reference to the Trade Union Act (2016). The second intent is to update the empirical literature on union resources. There is a relatively consistent set of public reporting requirements for British unions that has supported examination of resourcing since the Webbs (1907); this will be briefly summarised in section 2 (Certification Office returns, various years). Published work on this dataset currently ends in 2004 and we present data to 2014.

The structure of the paper is as follows. Section 2 outlines the approach and relates it to the existing literature on resources. Section 3 presents aggregate data on union resources, both those on the balance sheet and those not, for the period to 2014. Section 4 analyses the implications of this historical picture. Section 5 looks specifically at the largest British union, Unite, for the period since its formation in 2007; the purpose of this case study is to examine first and second-order problems at the level of the organisation. Section 6 examines the relationship between exogenous changes and 
endogenous problems by examining the implications of the Trade Union Act (2016), the net effect of which is likely to be primarily to increase second order collective action problems. Section 7 summarises the argument and concludes.

\section{Collective Action and Union Resources}

Olson's (1965) approach to collective action is to treat it as problematic; his key insight is to argue that public goods may not be provided even where everyone would be better off through their provision, primarily because of the free rider problem. Particularly where numbers are large, collective action is unlikely in the absence of two conditions; first, selective incentives refer to the introduction of private goods dependent on membership to supplement the public benefits of collective action and, second, special conditions refer to coercion or forms of constraint to encourage membership. For Olsen, these two devices go some way to solving the first order collective action problem, which is essentially how to get employees to join and stay in unions.

Several authors (e.g. Elster, 1989; 26-42, Kelly, 1998) have noted the logical problem with this, namely that in order for the collective action organisation to come into existence it needs already to exist in order to enforce the necessary conditions. Enforcement of the conditions is costly, and these costs form part of the second order collective action problem, which is controlling the costs of managing collective action organisations such that the costs are less than the sum of public and private benefits on offer. This second order problem is likely to be resolved, as Hirschman (1970) notes, under three conditions. First, where members' switching costs are high, higher costs of collective action will be borne. Second, where activists exist with different utility functions, costs are reduced; activists for Hirschman have a utility function in which the returns to collective action are not, as they are for ordinary members, financial returns minus costs but the sum of the two, since a positive value is put on activism itself. Third, where the benefits of collective action are experienced 
additionally by third parties (i.e. they have broader efficiency properties), the costs of collective action may be more widely spread.

We may relate these broad considerations about collective action to union behaviour. As Pencavel (1970) notes, unions provide three types of service to members. The first, collective representation, tends to generate public goods and thus does not solve the first order problem. Unions thus offer two other services (i.e. selective incentives), private benefits (for sickness or retirement, for example) and 'semi-collective' membership-dependent benefits such as representation in grievance or disciplinary processes; the delivery is to the individual member but it relies on a collective agreement. Unions also periodically resort to coercion (such as closed shop - compulsory membership - arrangements) or constraint (such as 'check off' where the employer deducts union subscriptions from salary) to solve first order problems. Falls in membership density under a collective agreement indicate failure to resolve a first order problem. Unions may try to counter this by augmenting the private goods through increased emphasis on benefits and representation to retain members, but this will tend to raise both costs, specifically expenditure per member, and subscriptions.

Second order collective action problems lead unions to raise member switching costs, perhaps by using seniority-related benefits. The use of activists, rather than full time union officers, as representativesmay substantially affect administrative costs, and unions may deliberately enhance representative structures to encourage activism specifically to reduce administrative costs (Fiorito et al, 1995; Willman, 2004); democracy may in fact be cheaper than oligarchy. Such activism is more likely where employers provide time off and facilities as subsidies for activists, and they are arguably more likely to do so where they see spillover benefits from collective action, such as employee voice (Gomez et al., 2010) or productivity improvements (Freeman and Medoff, 1984). Voice and the attendant efficiency improvements are, in Hirschman's terms, parts of the efficiency gain from collective action. 
Union financial measures are thus a key indicator of the viability of collective action. This much was understood by the Webbs $(1907 ; 162-283)$ who recognised the centrality of financial status and arrangements to secure 'permanent organisation' for the so-called 'new model' unions. However, understanding the role of such measures and arrangements has been the focus of just a few studies in the $20^{\text {th }}$ and 21 st centuries in Great Britain.

Roberts (1956) documented changes in aggregate income, expenditure and assets for the period 1936-50. He found substantial shifts in financial structure. Unions found it difficult across the period to raise subscriptions to keep pace with wages, prices or administrative expenditures per capita. Investment income filled the gap between subscription income and total expenditure; this income was, at that time, primarily yields from government bonds. Individual, friendly-society benefits declined as a proportion of total expenditure. Roberts argues, in effect, that the then newly-established welfare state (from the late 1940's) took over the primary role of benefit provider to all employees. Union benefits thus ceased to be a private good helping to solve the first order problem, and the resolution of second order problems of union operation absorbed more resources than revenue from membership could generate. Roberts closes his analysis with an expression of concern about the viability of the dominant union financial model in which investment income (either from asset returns or sales) balances the books.

Latta (1972) uses the same public dataset to examine the period 1960-70. One of his major concerns is a mismatch in resources between rich, manual unions with stable membership on the one hand and rapidly expanding but insolvent white collar unions on the other; the union movement's resources are seen to be in the wrong place. However, he notes widespread loss of assets and a general tendency for total expenditure to exceed total income. His conclusion is that there had been 'a marked decline from the period surveyed by Roberts' (1972; 409).

Again with the same dataset, Willman et al (1993) examined the entire period from 1950-1989 in order to complete the picture. The period embraced three 
discrete patterns of membership change; steady growth to 1965, very rapid increase from 1965-1979 and then sharp contraction from 1979 to 1989. These trends were not highly correlated with financial changes. Real total income tracked real total expenditure for the whole period, with a margin of approximately $10 \%$. Benefit expenditure continued to shrink. However, membership growth in the period 1965-1979 was associated with a halving of the value of union funds in real terms. This was a period of high inflation, and it may be that union assets were not inflation proof, or that the costs of membership acquisition exceeded the financial returns. However, from 1965 onwards, total subscription income from members averaged approximately $90 \%$ of total expenditure. Over the same period, the number of 'years of expenditure' held by unions in funds fell from 3.6 years to 1.2 years (Willman et al 1993; 7-19).

One interpretation of these trends is as follows. Income from members is not sufficient to resource a full solution to the second order collective action problem, as evidenced by total expenditure. The gap is covered by selling assets. In the aggregate, unions did not over this period increase the ratio of subscriptions to average earnings; in fact, it fell from $0.42 \%$ of pre-tax average earnings in 1950 to $0.31 \%$ in 1980 , a period in which private goods - benefits - also declined as a proportion of total expenditure. Paradoxically, the 1980's, a troubled decade for British unions in many respects including membership loss, showed an increase in this subscription ratio (to $0.37 \%$ at the end of the decade) and a substantial increase in returns on assets as unions moved resources from bonds to equities and property (Willman et al.1993; 15).

A final study, Willman and Bryson (2009) extended this work in two ways. First, it extended the study of this dataset to 2004. In this period, which is also one of membership contraction (from 1990 to 1997) then stagnation, solvency margins remained slim (3\%), but income from members increased faster than average earnings and the value of reserves increased faster than prices (though slower than stock market indices). However, expenditure rose fastest, such that by 2004 the union movement had a historic low of 1.06 years of expenditure in reserves. 
The second element of this 2009 study is to attempt to assess unions' 'off balance sheet' resources. The dataset on statutory returns covers the balance sheet of the union as a formal reporting organisation. It does not consider the 'Hirschman' elements of activist support for collective action or employer subsidy of union activity. For the period 1984-2004, Willman and Bryson use the WERS workplace data to attempt to assess trends in 'off balance sheet' resource for union activity. They construct a three item index - check off of union subscriptions from salary, management recommendation of union membership, and the presence at the workplace of a union representative. This index declines from 2.19 in 1984 to 1.69 in 1998, rising slightly to 1.78 in 2004. It should be noted that, given the decline in union density under collective agreements over this period, this may actually represent an increase in off balance sheet resource per member. However, observing that off balance sheet resource declines over the period by a greater proportion than on balance sheet resource, they conclude that this reduction in hidden resources for collective action is in fact ' a major pressure on union balance sheets' (Willman and Bryson, 2009;42).

In summary then, the data imply major endemic financial problems for British unions in solving first and second order collective action problems, at least until 2004. Union members pay a very small proportion of earnings as subscriptions and receive limited private goods in return. Coercion, in the form of closed shop arrangements, was never widespread and declined rapidly in the late $20^{\text {th }}$ century until it became legally unenforceable in the early $1990 \mathrm{~s}$ (Millward et al, 2000; 150). The second order problems are evident. Union members do not have high costs of shifting out of union membership; the wage premium is not large in the UK (Blanchflower and Bryson, 2004) and is in many cases a public good within unionised workplaces. Activism and employer support appear to be in decline. The outcome variables are a reduction in union funds in the aggregate generated by the need to subsidise current activity from reserves. We discuss the economic model at the source of these problems in Section 4, but first we update the data analysis to 2014. 


\section{Data Analysis.}

This section of the paper brings the picture more closely up to date by using both the statutory returns and the WERS dataset; the former extends to the financial year 2013/14 whilst the latter covers the period to 2011. The core elements of the story remain largely unchanged, but there are some additional elements, not least to do with trends in average earnings and asset returns across the financial crisis

\section{Figures 1 and 2 about here}

Figure 1 contains a membership concentration story². The number of unions continues to fall at a faster rate than the number of members. The primary mechanism is merger or transfer of membership, so the effectiveness of postmerger integration becomes an important ingredient in the solution of the second order collective action problem. A second issue is that, because the size distribution of unions is increasingly skewed, the aggregate picture becomes much more susceptible to the influence of events in the largest unions. We shall return to both points below.

Figure 2 shows continued low income growth and low solvency. The main change from previous years is the increased expenditure volatility, with spikes in 2005, 2008 and 2011. The 2008 spike is partly a function of expenditure increases across unions with the fallout from the financial crisis, but in all three years, specific second-order problems emerge which we discuss below. Figure 3 shows further deterioration in union reserves and the acid test ratio (funds/expenditure), driven by rapidly rising and volatile expenditure. Throughout this period, income per member moves on its historical trend with

\footnotetext{
${ }^{2}$ In the figures that follow, we exclude returns from two organisations of medical employees, the British Medical Association and the Royal College of Nursing. These are sizeable membership organisations, but they are also professional bodies with professional training businesses that financially dwarf their representational activities. BMA includes this income in its returns, RCN does not. The latter organisation does not regard its assets as relevant to its returns and thus returns $£ 0$.
} 
average earnings, but per capita expenditure increases much more rapidly than the index of consumer prices.

We also have WERS data on the off balance sheet resources, slightly different in format from the earlier index and covering the additional period 2004-11; these are presented in Table 1. Conditional on recognition, unions' off-balance sheet resources fell sharply through the late $80 \mathrm{~s}$ and $90 \mathrm{~s}$, but have since been roughly stable in the period 2004-11Putting this alongside the picture of a general continued deterioration in on balance sheet resources, it appears that, although it is impossible to assess the absolute size of each resource set, off balance sheet resources may be more important to union functioning at the end of the period compared to 2004. Put another way, any threats to off balance sheet resources are likely to be more serious at the end of the period.

\section{Table 1 about here}

On balance sheet, the picture is at least more buoyant in the second decade of the centurythan in the first. Membership is still falling, income per member and total income rise, but there is a substantial reduction in overall expenditure across the three years, and funds thus slightly recover. The acid test ratio stands at 1.02 in the aggregate. It remains the case that the costs of collective action exceed income from members by over $20 \%$ in each year.

Overall, then, the 'business model' for collective action does not differ substantially in 2014 from that identified by Roberts for a much earlier period. Unions do not cover the costs of servicing members from membership income. They rely on other income to fill this gap, and this income is normally from investment yields or disposals. Ironically perhaps, where investment yields are good, this model is more robust, and even more so where good investment yields and growth in real earnings coincide. Thus the 1980's, with rises in both financial measures but large falls in union membership, was rather better for unions in resource terms than the 1970's, which saw massive membership growth but high inflation exerting downward pressure on real 
earnings and with union asset returns poor across a wide range of asset classes. The contrast between these two decades in financial terms indicates the importance of exogenous influences on union resources. Perhaps a paradox for British unions is that the circumstances that drive membership increases and thus help with first order problems also create substantial second order collective action problems for the organisations concerned.

\section{Unions and the Cost Disease}

In a series of papers (Baumol and Bowen, 1966; Baumol, 2012; Flanagan, 2012), Baumol and colleagues have analysed what they term the 'cost disease'. This affects several sectors of the economy that deliver personal services - the main examples they use are from health care, education and the performing arts - in which costs tend to rise consistently faster than inflation, because the labour input of service delivery is difficult to reduce. Baumol characterises these as 'stagnant sector services' (the stagnation referred to is in productivity growth) and contrasts them with 'progressive' sectors - the examples used here are computers and electronics - in which technology leads to rapid increases in productivity and reduction in real unit costs and thus the prices of goods.

Costs in the 'stagnant' sector do not in this approach rise primarily because of general inflation, or because of excessive wage demands in the 'stagnant' sector. The problem is rather relative productivity growth. Salaries in the 'stagnant' sector tend to rise at broadly the same rate as those in 'progressive' ones, but since the percentage of total costs represented by labour costs is falling rapidly in the latter, but maintained in the former, only the former suffer from the 'cost' disease. Baumol et al (2012) document the falling labour hours per unit in a number of manufacturing sectors internationally but comment that it takes the same amount of labour to play a Mozart quartet as it did when he wrote them. In the 'stagnant' sector, labour input is a prime indicator of quality and standardisation is hard. Although some organisations combine 'stagnant' and 'progressive' elements (for example R\&D and manufacturing respectively 
in computers), many organisations in the 'stagnant' sector are long term members of it and experience continually rising real unit costs. In the three sectors mentioned - health, education and performing arts - survival is only possible with private or public subsidy, since rising real costs naturally lead to falls in demand. Baumol's argument is that 'stagnant' sectors will come to claim much higher percentages of consumer expenditure in future, while progressive sectors will, through continual productivity growth, claim less. Without consumer acceptance of this shift, these stagnant sectors will go into decline.

Our argument here is that unions may be seen as cost disease organisations. We have, of course, no direct measures of productivity growth for UK unions ${ }^{3}$, but the literature and data above show that, in the long term, trade union expenditures have tended to rise faster than inflation, and for most large unions, the major expenditure item is salaries of union staff. By contrast, the share of average earnings paid as subscriptions to unions is broadly static over the long term. Where real wages of members increase rapidly, subscription levels may also increase, but there will then be concomitant increases in union staff costs. By contrast, when real wages in the economy are static, subscription revenue has tended to be similarly constrained. We have seen that, since unions use asset income to cover shortfalls in income over expenditure, real increases in asset prices act in a way similar to external subsidy in other sectors, balancing the books.

There are several other aspects of the cost disease model to note relevant to the analysis of UK unions.

1. Many unions use indexation, both for subscriptions of members and salaries of staff. Members' subscriptions are indexed to either wages or prices and staff salaries are often pegged to some index or key point of members' salaries. This has two substantial benefits. The pegging of subscriptions and salaries avoids transactions costs manifest in

\footnotetext{
${ }^{3}$ Breda et al attempt a productivity measure using data from US union locals; their measures are membership growth and sales per employee. (Breda et al., 2016)
} 
debates at conferences over what members pay and what union officials get. Second, it operationalises an idea of fairness; members pay when the union raises their real income, and unions show, as employers, they are as fair as their negotiating counterparts. However, these mechanisms more or less ensure the shortfall of subscription income over total costs. The price elasticity of demand for union membership is an important issue, since a relatively small increase of the 'wage share' of union subscriptions would reduce the second order collective action problem.

2. Expenditure issues are primarily dependent on the problem that the union is both a representative organisation and an employer, with fixed short term employment costs. One of the key insights of the cost disease literature is that in the key sectors, costs are controlled by getting consumers (parents, relatives, volunteers) to complete some service work for free. The operational definition of this in the union sector is member activism, and, other things equal, the greater the level of activism, the easier it is to alleviate the cost disease problems unions face.

3. UK unions have little direct endowment from private sector donors or public funding. However, if they provide, as both Hirschman and Freeman and Medoff argue, efficiency gains for firms and wage premia for members, then there may be the prospect of generating resources from both to solve the cost disease. We return to these issues in conclusion, but first let us examine events in the resourcing of the largest UK union, Unite.

\section{Unite the union}

We will attempt to understand some of the second order issues rather better with a case study of the largest British union, Unite. Unite was formed by merger or, more accurately, by a series of mergers and transfers of engagements of members. In 2001, two large, and mainly private sector unions Manufacturing Science and Finance (MSF) and the Amalgamated 
Electrical and Engineering Union (AEEU), merged to form AMICUS (not an acronym). In 2004, AMICUS absorbed two industrial unions, GPMU (printing) and UNIFi (finance); both of these were themselves the product of prior mergers. In 2007, Unite was formed when AMICUS itself merged with the largest general union, the Transport and General Workers' Union (TGWU). The result was formation of the largest union in the statutory returns, accounting for over $25 \%$ of total union membership, and a substantially higher proportion of TUC membership. It runs both administratively and on a representational basis with a matrix structure, the two axes of which are geographical region and industry group.

As noted above, merger and transfer of engagements are the primary mechanisms driving membership concentration in UK unions. The motives for serial merging are complex but the trend is long term. Some mergers appear to be the result of financial fragility of one or more party, others are attempts to avoid or mitigate inter-union competition (Undy, 2008). What is clear is that few generate robust economies of scale in membership servicing that might alleviate second-order problems (Aston 1987; Willman et al, 1993), and one reason for this may be that merger agreements tend to protect incumbent rights.

The on balance sheet performance of Unite is shown in Table 2. Since formation, membership has fallen by $28 \%$, but income per member has doubled in nominal terms. Total income has increased by $48 \%$ and total expenditure by $30 \%$ but this apparent good expenditure performance masks the substantial expenditure spikes in the interim period, particularly just after merger. For most of its short life, Unite has had solvency $<1$, and this has affected the union's funds. Net worth declined to only $17 \%$ of its 2007 level by 2012 , before recovering the following year. However, in 2013, the acid test ratio for the country's largest union stood at only 0.6 , i.e. little more than 7 months of expenditure in reserve, and by no means all of this liquid.

That $75 \%$ of the original membership total would come to pay $150 \%$ of the original income from members indicates robust willingness to pay for the 
union's services and by 2013 membership income was, unusually for a British union, covering total expenditure. However, the expenditure spikes in Table 2 (which incidentally mirror those in the aggregate in Figure 2 above) have led to depletion in union funds.

What might cause an expenditure spike for a union? Administrative expenditure dwarfs benefit expenditure and the largest expenditure items tend to be recurrent. Normally salaries and expenses of union staff are by far the largest item (about 50\% for Unite), followed by subsidies to branches (about $10 \%$ in Unite) then occupancy and office costs and property repairs. Unpredictable or non-recurrent items would normally relate to campaigns or disputes, involving legal and balloting costs, strike pay or additional conference expenses.

In this case, Unite was financially badly hit by liabilities arising from its responsibility as an employer, specifically relating to actuarial losses on the final salary pension schemes covering union officials and staff. Over the period covered by Table 2 and in particular just after the merger, large losses of this sort were set against expenditure. Across the entire period, such losses were over $£ 175$ million net, set against the nominal funds loss in Table 2 of approximately $£ 160$ million.

These liabilities are not unique to Unite, or indeed even to unions as a whole. Pension fund deficits on final salary schemes, and the accounting rules for dealing with them, cover all employing organisations with funded schemes. However, there are particular vulnerabilities for unions. First, for financially fragile organisations, the absolute amounts involved can be very high, as the Unite case shows. Second, most unions have provided generous schemes to their own staff, mirroring their concern for many years that employers with whom they bargain should provide generous pensions. The third point is a matter of timing. Although it is difficult to get accurate figures, most current unions expanded their employment of officials in the 1970's and early 1980s, a time of widespread adoption of final salary schemes and, from a cohort 
perspective, likely to peak their liabilities in the current decade and the next, as staff retire and the contribution base shrinks.

\section{Table 3 about here}

The returns allow us to examine this phenomenon for Unite in more detail. Each return from a union must contain an FRS17 disclosure. FRS17 is the Accounting Standard governing disclosure of the financial status of UK pension schemes, both defined benefit and defined contribution; increasingly, defined benefit schemes have proved difficult to fund. Each year, unions must disclose details of the assets and liabilities of their pension funds in the accounting period that the liabilities arise, and at the market price of the assets. Put simply, if the scheme's assets decrease, or the liabilities increase, this must show up as a charge in the income and expenditure statement for the union in the statutory return and the union may be required to indicate provisions for any shortfall in the scheme.

Unite at merger inherited five final salary pension schemes covering union staff; these were inherited from unions that had transferred members, assets and liabilities into the merged entity. Four of these schemes were in deficit at the merger. It also inherited some unfunded liabilities (i.e. commitments to pay pensions without any assets to back them). The total shortfall by year is depicted in Table 3. It increases rapidly between 2007 and 2009, as the value of the assets held by the five funds fell during the crash. They remained high while assets, particularly equities, recovered to 2013, indicating the increase in liabilities as the union sought to rationalise its employment base postmerger; many of these costs fell on the pension scheme. In 2012, the union consolidated its pension schemes from 5 to 2, presumably to generate administrative economies of scale, and Policy Conference that year passed a motion ${ }^{4}$ requiring control over the level of severance payments to staff. Pension deficits then began to fall, but remain high.

\footnotetext{
${ }^{4}$ Policy Conference decisions, page 57. Unite website, accessed March 2016
} 
The key points we would draw from this are as follows. Unite shows the characteristics of a cost disease organisation, with expenditure items difficult to control and revenues - particularly where, as after 2008 in UK, real earnings stagnate and membership declines - difficult to increase in the long term. Merger is the preferred mechanism in UK unions for consolidating membership, but the example indicates that it is difficult for unions to reduce costs related to their employer role since they cannot, as socially responsible non-profit organisations, pursue post-merger rationalisation as rigorously as private sector firms might. Employment costs tend to turn into fixed costs for such organisations. In particular, the incidence of defined benefit pensions schemes and their liabilities, combined with mark to market accounting, as described above in IFRS17, mean that union assets increasingly have to be used to fund pension fund deficits not regular items of current expenditure. There are powerful endogenous forces complicating second order collective action problems. In the next section we look at an instance of an exogenous pressure in the same direction.

\section{The Trade Union Bill 2016}

Historically, the industrial relations system in Great Britain has attracted descriptions such as 'informal' and 'voluntaristic' (Kahn-Freund, 1972), terms which differ in meaning but signal a relative absence of legal or regulatory intervention. Indeed a key element of collective action has been immunity from prosecution for acts such as encouraging breach of contract which in other domains would attract liability. The issue for our purposes is that informality and voluntarism tend to lower union on balance sheet costs by reducing compliance costs, since this voluntaristic approach has broadly extended to the regulation of union administrative affairs. Let us give two examples, of first and second order collective action problems. If a union may convince an employer to hand out union membership forms to new hires, then 
deduct the subscriptions from salary without charge, the union's costs of membership acquisition are substantially reduced. If individual rights legislation is passed preventing this, these costs massively increase. The former will not appear on the balance sheet, but the latter will. Second, if a union activist may call a strike to secure union recognition and the issue is resolved, then none of this shows up in the union's accounts. If any strike must be supported by a ballot organised by the union, it does, and ballot costs may be substantial. These two examples are also illustrative of the general point that many second order collective action costs may be borne by employers and activists respectively.

A recent piece of legislation by the UK Parliament seeking to formalise certain aspects of union operation is likely to have substantial balance sheet implications. A principal element of the 2016 Trade Union Bill seeks to address the conduct of strikes. <Measures such as permitting the use of agency workers by employers and regulating picketing more closely, together with a threshold requirement of $50 \%$ turnout in ballots, plus the more stringent requirement of a $40 \%$ vote in favour of strikes in certain essential services have caused the TUC to title its campaign against this proposed legislation 'Protect the Right to Strike'.

These issues are clearly important to unions but, from a financial point of view, there are arguably other elements in the provisions on formalisation and regulation that might have a substantial impact on a financially weak set of unions. Table 4 classifies the measures proposed in the Bill in terms of impact on revenues, assets and costs. The cost implications are easily the most significant, and they relate to on and off balance sheet issues.

Table 4 about here

Opting into political fund contributions is likely to reduce revenue, but political funds are small relative to general funds. Removing the option in the public sector for union members to pay subscriptions through salary will have a substantial impact, given the high proportion of total union membership in the 
public sector. The main alternate efficient method is by direct debit from bank accounts, but the transactions costs of switching may be high. The public sector has a higher density of union membership under bargaining coverage than the economy as a whole, and this may decline further.

Assets are more at risk by further restrictions on immunity from prosecution and from the new ability of the Certification Officer to enforce financial penalties of up to $£ 20,000$. There is also a requirement for an enhanced reporting of expenditure data.

However, the expenditure-related items are likely to be the most important. Balloting is costly in a direct sense- Unite spent almost $£ 1$ million on nonindustrial ${ }^{5}$ ballots in 2013 - but there are also the attendant costs of securing up to date and comprehensive membership lists, and the costs of legal challenge to the lists. There are restrictions on the extent to which unions can use cheaper on-line methods to conduct ballots, so communication costs are likely to rise. The limiting of strike mandates will make balloting more frequent, and the costs involved may make smaller ballots for local strikes rather than larger ones for national strikes preferable to unions, again on cost and feasibility bases $^{6}$.

The monitoring and regulatory changes to facility time in the public sector may 'squeeze' off balance sheet resources in ways that substantially spill over to the union balance sheet. The bill proposes monitoring and subsequent regulation of such time in the context of a broad concern with the costs of the public sector. The majority of union members are in the public sector. A reduction in the time spent on union business by activists may generate a reduction in members' private goods (union services) or an increase in the amount of membership servicing by full time employees which will thus appear on the union's balance sheet as a cost increase.

\footnotetext{
5 This term excludes strike ballots and refers to those conducted as part of the union's democratic processes; i.e. they are likely to be recurrent expenditures.

${ }^{6}$ Personal communication, General Secretary, Association of Teachers and Lecturers.
} 


\section{Discussion and Conclusion}

In this paper, we have tried to present a thorough analysis of the resource position facing British unions in order to present a discussion at this stage of strategic issues and options. In section 2, we used existing literature to argue that there are structural flaws in the collective action model used by British unions in the aggregate. This model has, since the period of Roberts' analysis, had a revenue component that relies on taking a broadly constant proportion of real earnings as income from members, and providing private as well as public goods to encourage membership growth. However, private goods are representative based, rather than benefits based, and depend on the solution to the second order collective action problem of how to provide the expected returns to members.

Empirically, the second order problem is that, because expenditure routinely exceeds income from members and rises in real terms, other income must secure solvency by filling the gap. Other income has been from investments and assets and the most pervasive story of the entire period since 1945 has been the erosion of the asset base in relation to expenditure. The costs of collective action fall to an unquantifiable degree on union balance sheets on the one hand and on members and their employees on the other. In theory, a union could exist entirely 'on balance sheet', in which case its costs would be substantial, or entirely 'off balance sheet', in which case employer subsidy and membership activity would support a very small union superstructure. There are empirical examples close to both conditions. In the 1980's the Inland Revenue Staff Federation (IRSF) decided to base its collective action strategy almost entirely on paid officials because of the opportunity costs of union activism for members on high pay (Willman et al, 1993; 101-21). On the other hand, the shop floor bargaining practices in engineering described in the research papers for the Donovan Commission in the 1960's depict an industrial relations system operating almost without reference to a formal union structure. So, there is substantial unobserved heterogeneity underneath the long run aggregate data but, in the aggregate, the British union business 
model can only work where union assets generate a continuous and sustainable revenue stream to subsidise the collective action model.

Section 3 presented data that indicate union reserves are, in the second decade of the $21^{\text {st }}$ century, so low that the risks associated with this model are high. Typically a union that finds at the organisational level it can no longer fund its activities seeks a merger partner. However, there is little evidence that larger organisations resulting from merger are capable of rectifying financial issues. The Unite case in Section 5 illustrated some of the financial issues including legacy effects of employment liabilities that such organisations face. This case may not be capable of generalisation, but there are several other large unions structurally and historically similar. The significance of Section 5, on the Trade Union Bill, is to show that any increase in accountability and regulation, whatever the ostensible legislative target, is likely to exacerbate the fundamental expenditure problem.

Finally, we return to the generic cost disease issues discussed in Section 4. We have characterised unions as a species of, in Baumol's terminology, 'stagnant' sector services, characterised by high levels of labour input, low productivity growth and remorseless cost pressures. In the other sectors characterised by such economic features, such as health, education and the performing arts, the solutions to organisational survival take at least two forms; first, convincing customers to devote a greater proportion of their total expenditure to the service in question and, second, securing state funding or private endowment to subsidise operational activities. These may not seem at first sight relevant to unions, but we suggest that they are.

For UK unions, addressing the first option means exploring the price elasticity of demand for union membership. Since Roberts' early analysis, UK unions have taken a very small $(<1.0 \%)$ fraction of UK average earnings as subscription income and, even within this narrow $1 \%$ band, there is no clear sign of increase. Currently, the percentage is less than $0.5 \%$. An argument has been made that inter-union competition has caused a race to the bottom in terms of union membership pricing, but as the number of unions diminish 
and membership concentration increases the competitive pressures must diminish and the possibilities of price coordination increase. British unions may need to test out members' willingness to pay higher subscriptions (as a percentage of earnings) than has historically been the case.

The second option, securing state or private subsidy, may also seem less relevant for unions than, say, performing arts. Nevertheless, the key insight here is that the behaviour of public actors (government, specifically legislators) and private ones (specifically unionised employers) are sources of subsidy for collective action. The content of employment and industrial relations legislation has a substantial impact not only on union rights but on union costs. Unions have always sought legislation to enhance union rights but perhaps have not focused as much on the second order collective action effects of legislation. On the other hand, the contribution of employers through provision (or concession) of union facilities has historically been very important to union viability in financial terms. The patchy evidence available is that it has been in decline for some time, and that this has increased the second order problems on union balance sheets.

In summary, then, the survival strategies of other forms of cost disease organisation may become very relevant to UK trades unions. One might say that, since the second order problems in 2014 are fundamentally the same as those identified Roberts in the 1950's and unions persist, then they may carry on with current economic models of organisation. Against this we would make the following points. First, on some measures, particularly the asset base and the returns on assets experienced by UK unions, the situation is very much worse. A common theme of work on union finances since Roberts is deterioration. Second, the historical evidence from the UK is that solving the first order collective action (raising membership) does not solve the second order problem (union survival); in fact the evidence of the 1970's points to the reverse. In a cost disease sector, growth may actually make things worse. 


\section{$\underline{\text { References }}$}

Aston, B. (1987) "Trade union mergers in Britain, 1950-82", unpublished PhD thesis, London School of Economics.

Baumol, W.J. (2012) The Cost Disease; Why Computers get Cheaper and Health Care Doesn't, New Haven, Yale University Press.

Baumol, W.J. and Bowen, W.G. (1966) Performing Arts; The Economic Dilemma, Cambridge, MIT Press

Blanchflower, D. and Bryson, A. (2004) "What effects do unions have on wages now?" Journal of Labor Research, 25, 3, pp383-414.

Breda, A., Bryson, A. and Forth, J. (2016) " Competition and Productivity; The case of union locals" working paper, University College London.

Brown, W.B., A Bryson, J Forth and K Whitfield (eds) (2009) The Evolution of the Modern Workplace, Cambridge, Cambridge University Press.

Buchanan, R. (1981) "Union Concentration and the Largest Unions" British Journal of Industrial Relations, Vol.19 No.2, pp232-7.

Certification Officer. Annual Report of the Certification Officer. London, Certification Office, various years.

Charlwood, A. and J. Forth (2009) "Employee representation", pp.74-96 in W Brown, A Bryson, J Forth and $\mathrm{K}$ Whitfield (eds) The Evolution of the Modern Workplace, Cambridge University Press.

Elster, J. 1989. The Cement of Society. Cambridge, Cambridge University Press.

Fiorito, J., P. Jarley, and J. T. Delaney (1995) "National Union Effectiveness in Organizing; Measures and Influences." Industrial and Labor Relations Review Vol. 48 No. 3 pp 613-635.

Flanagan, R. (2012) The Perilous Life of Symphony Orchestras, New Haven, Yale U.P. 
Freeman, R. and J. Medoff (1984); What Do Unions Do?, New York: Basic Books

Gomez, R., A. Bryson and P. Willman (2010) "Voice Transformation: The Shift from Union to Non-Union Voice in Britain" in Oxford Handbook of Participation in Organisations , (ed) Wilkinson et al., Oxford University Press, 2010

Hirschman, A. 1970. Exit, Voice and Loyalty. Cambridge, Harvard University Press

Kahn-Freund, O (1972) Labour and the Law, Oxford, Blackwell.

Kelly, J. (1998) Rethinking Industrial Relations, London, Routledge.

Latta, G. (1972) "Trade Union Finances", British Journal of Industrial Relations, Vol 10 No. 2

Olson, M. (1965) The Logic of Collective Action; Public Goods and the Theory of Groups, Cambridge, Harvard University Press.

Pencavel, J. 1971. "The Demand for Union Services; An Exercise" Industrial and Labor Relations Review, Vol. 24, No. 2, pp180-190.

Roberts, B. C. 1956. Trade Union Government and Administration London: Bell and Sons.

Undy, R. 2008 Trade Union Merger Strategies, Oxford University Press

Webb, S. and Webb, B. 1907. The History of Trade Unionism. London: Longman Green and Co.

Willman, P. 1996. "Merger propensity and merger outcomes among UK unions, 1986-95." Industrial Relations Journal, Vol. 27, No, 4 pp. 331-9

Willman, P. 2004. "Structuring unions; the administrative rationality of collective action." In John Kelly and Paul Willman, eds. Union Organization and Activity. London: Routledge, pp. 73-89.

Willmn, P. (2005) "Circling the Wagons; endogeneity in union decline" in David Metcalf and Susan Fernie (eds) British Unions; Dissolution or Resurgence?London, Routledge.

Willman, P. and A. Bryson (2009), "Accounting for Collective Action; Resource Acquisition and Mobilisation in UK Unions", Advances in Industrial Relations, Volume 16, p23-50.

Willman, P., T. J. Morris and B. Aston. 1993. Union Business; Trade Union Organization and Financial Reform in the Thatcher Years. Cambridge: Cambridge University Press, 1993. 
Figure 1: Numbers of members and unions, 1999/2000-2013/14

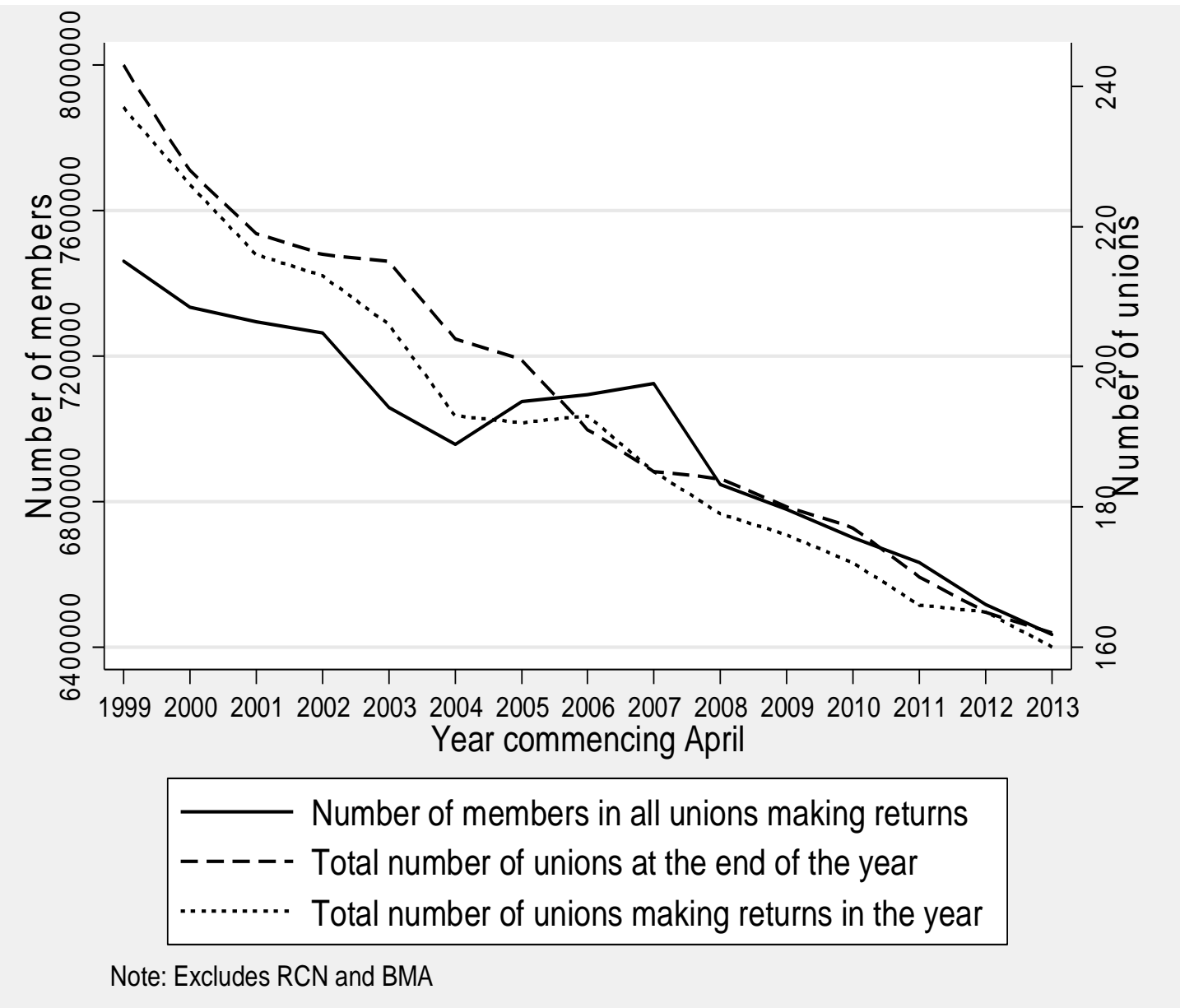

Source: Certification Officer Annual Reports 
Figure 2: Income, expenditure and solvency, 1999/2000-2013/14 (indices $1999=100)$

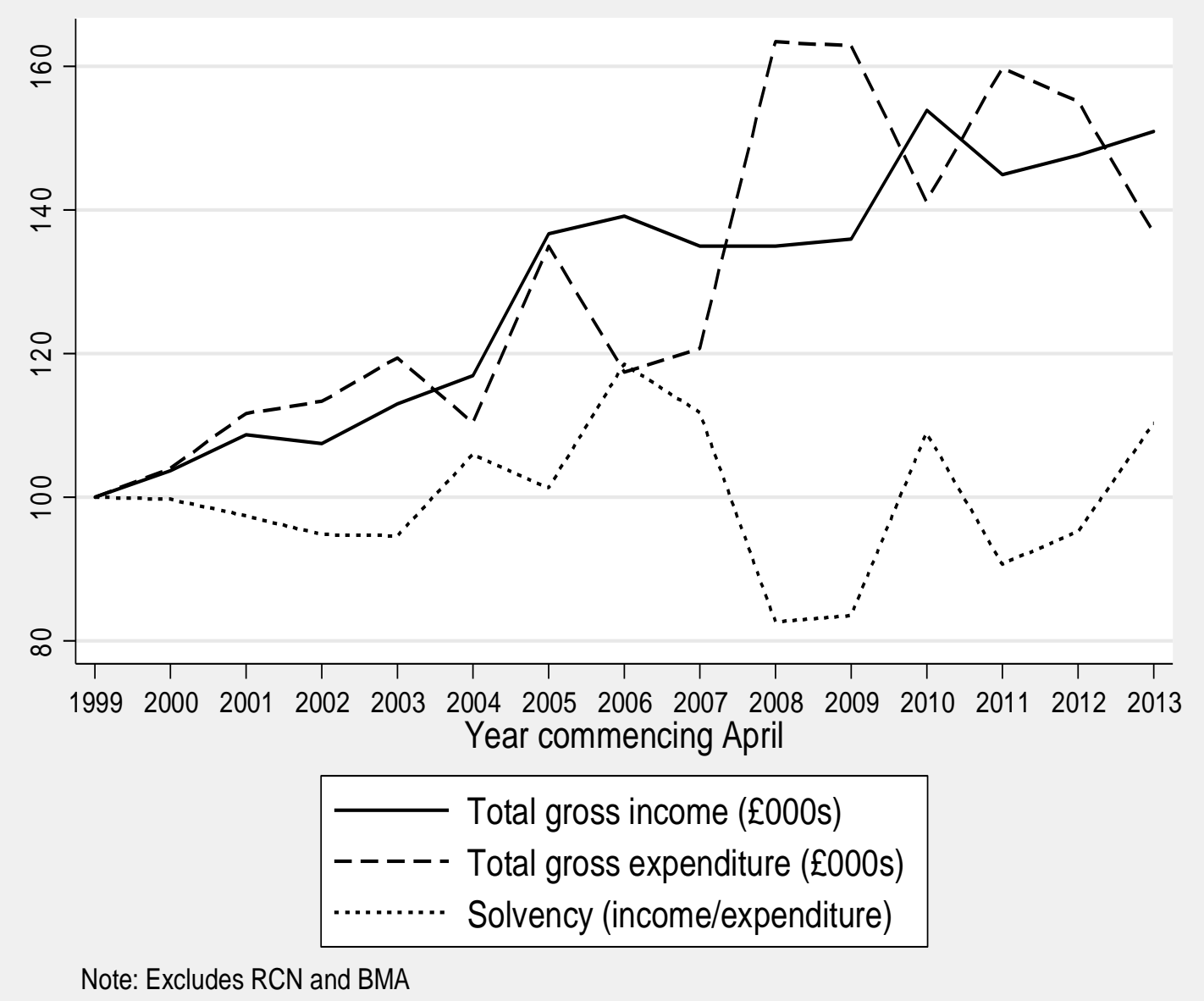

Source: Certification Officer Annual Reports 
Figure 3: Total funds, expenditure and acid-test ratio, 1999/2000-2013/14 (indices 1999=100)

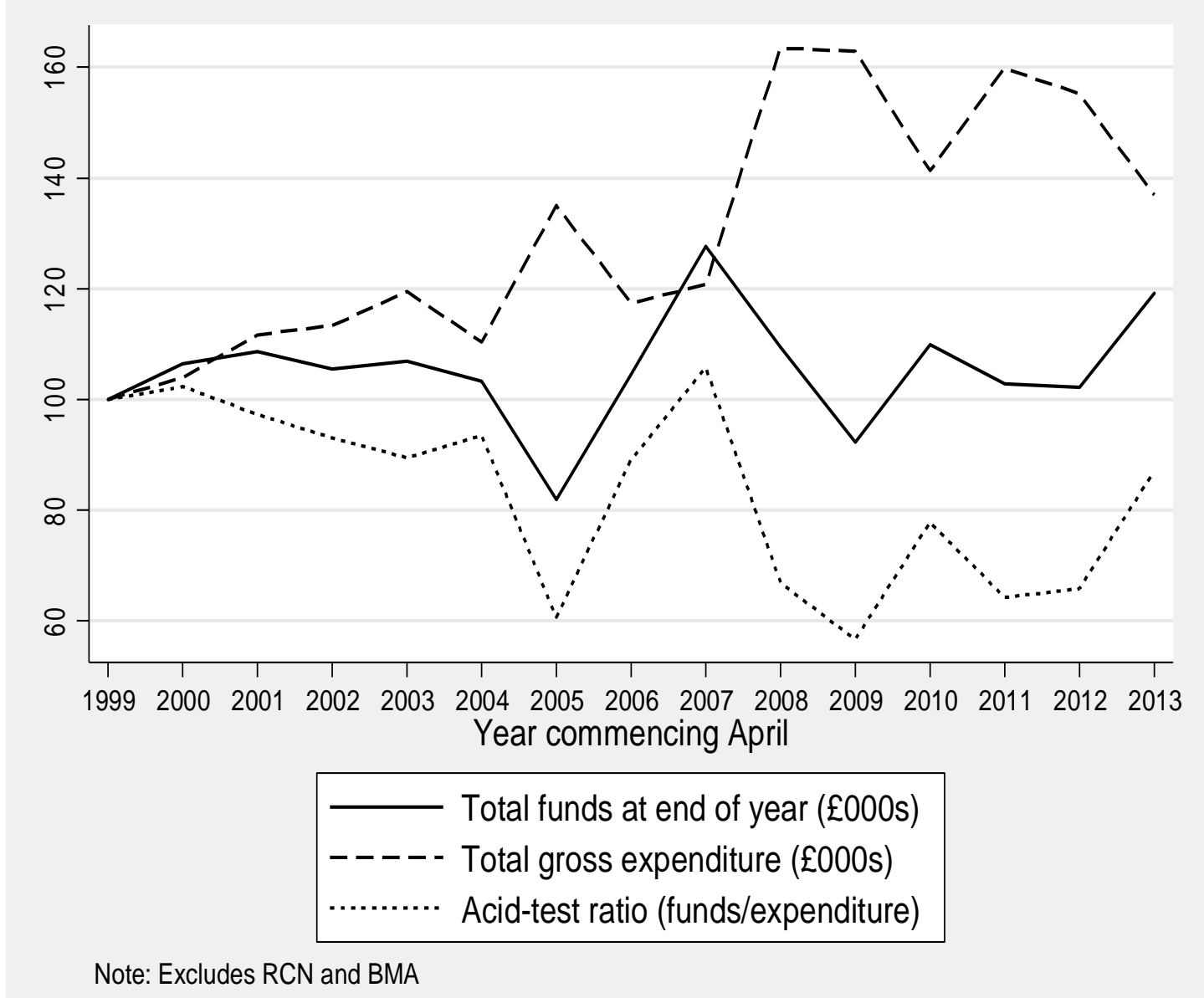

Source: Certification Officer Annual Reports 
Table 1: The Distribution of Off-balance Sheet Support for Unions, 19842011

\begin{tabular}{|c|c|c|c|c|c|}
\hline & 1984 & 1990 & 1998 & 2004 & 2011 \\
\hline Any recognized unions & 66 & 53 & 41 & 38 & 36 \\
\hline \multicolumn{6}{|l|}{$\begin{array}{l}\text { Where unions are } \\
\text { recognized: }\end{array}$} \\
\hline Check-off & 80 & 86 & 75 & 75 & 80 \\
\hline $\begin{array}{l}\text { Managers require or } \\
\text { strongly } \\
\text { recommend union } \\
\text { membership }\end{array}$ & 58 & 42 & 22 & .. & .. \\
\hline $\begin{array}{l}\text { Managers in favour } \\
\text { of union } \\
\text { membership }\end{array}$ & .. & .. & 62 & 65 & 63 \\
\hline $\begin{array}{l}\text { Any on-site union } \\
\text { representatives }\end{array}$ & 83 & 72 & 69 & 62 & 63 \\
\hline $\begin{array}{l}\text { Index } 1 \text { (mean) } \\
\text { Index } 2 \text { (mean) }\end{array}$ & 2.20 & 2.02 & $\begin{array}{l}1.63 \\
2.07\end{array}$ & 2.03 & 2.06 \\
\hline
\end{tabular}

Bases: all establishments with 25 or more employees recognising trades unions, excluding those with missing data.

Figures are column percentages, with means presented in the last row 
Table 2

Unite Annual Returns

2007-14

$(£ 000)$

\begin{tabular}{lccccc} 
Year & Members & $\begin{array}{l}\text { Income from } \\
\text { Members }\end{array}$ & $\begin{array}{l}\text { Total } \\
\text { Income }\end{array}$ & $\begin{array}{l}\text { Total } \\
\text { Expenditure }\end{array}$ & $\begin{array}{c}\text { Year end } \\
\text { Funds }\end{array}$ \\
$2007 / 8$ & 1952226 & 102341 & 112499 & 100908 & 240580 \\
$2008 / 9$ & 1635483 & 149053 & 151298 & 213319 & 175559 \\
$2009 / 10$ & 1572995 & 146689 & 151834 & 226976 & 103417 \\
$2010 / 11$ & 1515206 & 152489 & 163000 & 187758 & 78659 \\
$2011 / 12$ & 1510026 & 143323 & 156880 & 174470 & 61069 \\
$2012 / 3$ & 1424303 & 151302 & 164391 & 183516 & 41944 \\
$2013 / 4$ & 1405071 & 151136 & 167216 & 131149 & 78011 \\
\hline
\end{tabular}

Source; Certification Office Returns

Note: Unite returns are for the years ending 31 December in the first mentioned year. 
Table 3: Total Liabilities of Unite Pension Funds 2007-14

Year Liabilities*

(£000)

2007

18583

2008

52099

2009

137325

2010

103344

2011

121288

$2012^{\star *}$

144010

2013

118002

2014

92214

Source; Certification Office FRS17 Disclosures

Notes;

*Scheme deficits plus unfunded obligations

${ }^{* *}$ Consolidation from 5 to 2 schemes 
Table 4:Impact of the Trade Union Act

Revenue

Opt into political funds

Assets

Restrictions on immunity

Co sanctions and financial penalties

\section{Expenditure}

$50 \%$ voting threshold in ballots

$40 \%$ of member vote in essential services

3 month validity of strike mandates

More detailed expenditure data to $\mathrm{CO}$

Transparency of facilities time in public sector plus regulations

Levy on unions for $\mathrm{CO}$ costs (£1million) 